WANG, Z. M. and S. E. MACDOnAld (1992): Peatland and upland black spruce populations in Alberta, Canada: Isozyme variation and seed germination ecology. Silvae Genetica 41: 117-122.

Wang, Z. M., M. J. LeChowicz and C. Potvin (1994): Early selection of black spruce seedlings and global change: which genotypes should we favor? Ecological Applications 4: 604-616.
YANG, R.-C. (2002): Likelihood-based analysis of genotypeenvironment interactions. Crop Science 42: 1434-1440.

YeH, F. C., V. J. LIEFFERS and M. SuN (1993): Isozyme and morphological differentiation in upland and peatland black spruce, Picea mariana (Mill.) B.S.P. from NorthCentral Alberta. Genetics (Life Science Advances) 12: 71-77.

\title{
Genetic Performance and Maximizing Genetic Gain Through Direct and Indirect Selection in Cherrybark Oak
}

\author{
By J. P. Adams ${ }^{1), *)}$, R. J. Rousseau ${ }^{2)}$ and J. C. AdAmS ${ }^{3)}$
}

(Received $17^{\text {th }}$ March 2006)

\begin{abstract}
In 1987, an open-pollinated test of cherrybark oak (Quercus pagodae Raf.) was established on a loess site in Carlisle County, Kentucky. The test contained 37 halfsib families representing eight provenances from Louisiana, Mississippi, Tennessee, and Virginia. Height measurements were taken at ages one, three, five, ten, and fifteen, and diameter at ages five, ten, and fifteen. Significant differences existed among provenances and among families within provenances. Seed sources from the west-central Mississippi area performed better for both diameter and height, yet no overall geographic trend was apparent. The top three families were all from the Warren Co., Mississippi source while two of the top three diameter families were from Washington Co., MS and the third was from Warren Co., Mississippi. Survival among the eight provenances was constant from age one to ten. A drop in survival was shown between ages 10 and 15 , probably a result of inter-tree competition. Height and diameter growth between ages five and 10 was nearly double that prior to age five and between ages 10 and 15 . Family heritabilities for height and diameter were calculated for each measurement year. Family heritabilities for diameter ranged from 0.55 to 0.70 while height ranged from 0.50 to 0.70 . Strong age-age correlations for height, diameter, and volume were found indicating good trait predictability from early measurements. Genetic gain equations were used to identify the optimum selection age and trait for maximizing age 15 volume. Early selection of families within provenances should yield gains in height, diameter, and volume.
\end{abstract}

Key words: Cherrybark oak, provenance, genetics, selection, genetic gain

\footnotetext{
1) Mississippi State University, Department of Forestry, Starkville, Mississippi, USA.

2) ForestConcepts, LLC, Paducah, Kentucky, USA.

3) Louisiana Tech University, School of Forestry, Ruston, Louisiana, USA.

*) Communicating Author: Joshua Adams, Box 9681 Mississippi State, MS. Tel: (662)325-8359. Email: jpa18@msstate.edu
}

\section{Introduction}

Cherrybark oak (Quercus pagoda Raf.) is an important and highly valued southern hardwood timber species. The species range is from Maryland south to Florida, west to eastern Texas, and north to southern Illinois (STEIN et al., 2003). Usually this oak occurs in well-drained alluvial, lowland soils as well as loess bluffs. Reaching reproductive maturity between 15 to 20 years of age, this species is generally grown commercially for 40 to 60 years for timber production.

Previous studies have shown growth differences exist among provenances (GREEN et al., 1991 and SCHOENIKE et al., 1982). Neither of these studies identified any geographic trend in provenance productivity. Substantial variation among families within provenances was also observed by GREEN et al. (1991) which led to the recommendation that provenance and individual family considerations should be made during selection. Similar results were found in water oak $(Q$. nigra L.) in a provenance study that covered most of the geographical region in this study (ADAMS, 1989). While these studies found differences in growth characteristics among provenances, YUCEER et al. (1998) sampled cherrybark oak seed sources on an east to west transect within Mississippi and found no significant variation in seedling emergence and survival.

The objective of this study was to identify growth differences among various provenances. Determination of potential genetic gains through selection was conducted through estimation of heritability and calculation of genetic gain. The ability to indirectly select for maximization of volume at age 15 was studied.

\section{Materials and Methods}

\section{Plant Material and Experimental Design}

A cherrybark oak provenance-progeny test was established in 1987 on MeadWestvaco property located in 
Carlisle Co., Kentucky. The test site is on a silt-loam site, of the Memphis-Loring soil series. Although these soils are considered to be strongly acid with a medium content of organic matter and plant nutrients, this particular site had been limed and had a neutral $\mathrm{pH}$. The planting site had been historically in agriculture production until 1983, after which the land remained fallow. The site was prepared with herbicide and disking prior to planting.

The experimental design was split-plot design, with the main plots being the eight provenances. Six blocks contained 37 half-sib families that represented the eight provenances. Each family was planted in a five-tree-row plot. Planting spacing was 2.74-by-2.74 meters. The seedlings were collected from seed sources in: Bienville Parish, LA (LA1), Washington Parish, LA (LA2), Okitibbeha Co., MS (MS1), Warren Co., MS (MS2), Washington Co., MS (MS3), Fayette Co., TN (TN1), Lauderdale Co., Haywood Co, Fayette Co., Weakly Co., TN (TN2), and Southampton Co. VA (VA1) (Figure 1). Height measurements were taken at ages one, three, five, 10 , and $15 . \mathrm{DBH}$ measurements were taken at ages five, 10 , and 15 . Volume (cubic meters) was calculated using the volume equation: volume $=[0.0000785 \mathrm{DBH}$ $\left.(\mathrm{cm})^{2}\right] \times$ height $(\mathrm{m})$.

Acorns from five randomly selected seed trees from each of the eight provenances were collected during the fall of 1985. Seeds were floated in water to remove damaged or weevil infested seed and were stored in sealed plastic bags and placed in a refrigerator at $1.67^{\circ} \mathrm{C}$ until sowing. The seed were sown on April 14 to April 23, 1986 at a spacing of 97 seedlings per square meter at the J. P. Rhody Kentucky State Nursery located near Gilbertsville, Kentucky. Seedlings were lifted, graded, and stored in the MeadWestvaco coolers at Wickliffe, Kentucky following the first growing season and went through an additional grading prior to study deployment (HARI, 1988). The test site was disked twice during the first year, once during the second year and then mowed once at ages three and four. The primary herbaceous competitor was Johnson grass (Sorghum halepense L. Pers.) which overtopped the trees during the latter portions of the first and second growing season.

\section{Analysis}

Differences among provenances and families within provenances were tested with analysis of variance (ANOVA) using the SAS PROC GLM procedure (SAS Institute, 1999). Diameter, height, and volume were analyzed at each age of measurement. The random model used was:

$$
y_{i j k l}=\mu+\beta_{i}+\alpha_{j}+\lambda_{k(j)}+(\beta \alpha)_{i j}+(\beta \alpha \lambda)_{i j k t}+e_{i j k l}\left\{\begin{array}{l}
i=1, \ldots, 6 \\
j=1, \ldots, 8 \\
k=1, \ldots, 37 \\
l=1, \ldots, 5
\end{array}\right.
$$

Where $\beta$ was the effect of the $i^{\text {th }}$ replication, $\alpha$ was the fixed effect of the $j^{\text {th }}$ provenance, $\lambda$ was the random effect of the $\mathrm{k}^{\text {th }}$ family nested within $\mathrm{j}^{\text {th }}$ provenance, and e was the within plot variance. Block-by-family variance and within-plot variance was pooled into a single error term. Duncan's New Multiple Range Test was used to identify statistical differences among provenance means.

Narrow-sense individual tree $\left(\mathrm{h}_{\mathrm{i}}^{2}\right)$, family heritability $\left(\mathrm{h}_{\mathrm{f}}{ }^{2}\right)$, and within-family heritability $\left(\mathrm{h}_{\mathrm{w}}{ }^{2}\right)$ was calculated for each trait at each measurement age using the estimated variance components from the ANOVA. Heritabilities were calculated using the equations:

$$
\begin{aligned}
& h_{i}^{2}=\frac{4 \sigma_{f}^{2}}{\sigma_{p}^{2}}, \\
& h_{f}^{2}=\frac{\sigma_{f}^{2}}{\sigma_{p f}^{2}}, \\
& h_{w}^{2}=\frac{3 \sigma_{f}^{2}}{\frac{\sigma_{p l o t}^{2}}{b}+\frac{\sigma_{e}^{2}}{b n}},
\end{aligned}
$$

where: $\sigma_{f}^{2}$ was the variance between families, $\sigma_{p}^{2}$ was the phenotypic variance, $\sigma_{\mathrm{p} f}^{2}$ was the variance of family means, $\sigma_{p l o t}^{2}$ was the variance among plots, $\sigma^{2}$ e was the variance among individuals within plots, $b$ was the number of blocks, and $\mathrm{n}$ was the number of trees per plot (NAmKoONG et al., 1966). Standard error of heritability was calculated following methods of Osborne and PATERson (1952).

\section{Direct Response}

Response to three different selection techniques was studied. These included (1) mass selection in which the best individuals within the test are selected no matter what provenance or family they originate from. Propagation of these individuals could be clonal for some species but unlikely for oaks. Thus, they would need to be grafted into an orchard scenario which means their breeding value would be unknown until seed is obtained and tested. Use of (2) family selection was studied in which the best family is selected based on performance and individuals from this family (ideally grafts directly from the mother tree) are then grafted into an orchard scenario. Breeding value is known and backward selection is the process for establishing an orchard. Finally, (3) combined selection was studied in which the best family is selected and then the best individuals within that family are taken for grafting into a breeding bank or an orchard. However, this is a forward selection with the breeding value of the individual unknown.

An expected response ( $R$ ) from direct selection was determined using calculated heritability in the equations:

$$
\begin{aligned}
& \text { Individual expected response: } \mathrm{R}=i \sigma_{p} h^{2}{ }_{i} \\
& \text { Family expected response: } \\
& R_{f}=i \sigma_{f} h_{f}^{2} \text { (FALCONER and MACKAY, 1996). }
\end{aligned}
$$

The expected responses were compared using individual tree selection (mass-selection) or selection based on family means (family-selection). 
Family-selection was also compared to combinedselection (selection of best individuals within the best families). Predicted breeding values $(\hat{g})$ from familyselection and combined-selection of volume at age 15 were calculated and compared for determination of the best selection technique. Breeding values from familyselection were calculated using family heritability and the deviation of the $\mathrm{k}^{\text {th }}$ family from the overall mean in the equation:

$$
\hat{\mathrm{g}}_{k}=2 h_{f}^{2}\left[\overline{\mathrm{y}}_{. . k .}-E\left(\overline{\mathrm{y}}_{. . k .}\right)\right] .
$$

Breeding values from combined-selection were calculated using family heritability, within-family heritability, and deviations of both the $\mathrm{k}^{\text {th }}$ family from the overall population mean and the deviation of the best $i^{\text {th }}$ tree from its respective family mean

$$
\begin{aligned}
\hat{\mathrm{g}}_{i j k l}= & h^{2}{ }_{w} \times\left[y_{i j k l}-E\left(y_{i j k l}\right)\right]+\left(h^{2}{ }_{f}-h^{2}{ }_{w}\right) \\
& {\left[\overline{\mathrm{y}}_{. . k .}-E\left(\overline{\mathrm{y}}_{. . k .}\right)\right](\text { HODGE and WHITE, 1992). }}
\end{aligned}
$$

\section{Indirect Response}

Genetic, family, within-family, and phenotypic age-age correlations $\left(\mathrm{r}_{\mathrm{xx}}\right)$ of height, diameter, and volume with volume at age 15 were calculated using the following respective equations:

$$
\begin{aligned}
& r_{a_{1} a_{2}}=\frac{\operatorname{Cov}_{a_{1} a_{2}}}{\sqrt{\operatorname{Var}_{a_{1}} \operatorname{Var}_{a_{2}}}}, \\
& r_{F_{1} F_{2}}=\frac{\operatorname{Cov}_{F_{1} F_{2}}}{\sqrt{\operatorname{Var}_{F_{1}} \operatorname{Var}_{F_{2}}}}, \\
& r_{W_{1} W_{2}}=\frac{\operatorname{Cov}_{\Gamma_{1} W_{2}}}{\sqrt{\operatorname{Var}_{W_{1}} \operatorname{Var}_{W_{2}}}}, \text { and } \\
& r_{p_{1} p_{2}}=\frac{\operatorname{Cov}_{p_{1} p_{2}}}{\sqrt{\operatorname{Var}_{p_{1}} \operatorname{Var}_{p_{2}}}} .
\end{aligned}
$$

Correlation response (CR) for each of the selection methods was calculated for each trait at each juvenile age (i.e, age was less than or equal to age 10). The correlated response calculation for mass-selection, familyselection, and combined-selection used the following respective equations:

$$
\begin{aligned}
& \mathrm{CR}_{\mathrm{M}}=i_{1} r_{A} \sigma_{P Y} h_{X} h_{Y}, \\
& \mathrm{CR}_{\mathrm{F}}=i_{2} r_{p_{F}} \sigma_{P_{F} Y} h_{F Y} h_{X} \text {, and } \\
& \mathrm{CR}_{\mathrm{C}}=i_{3} r_{p_{W}} \sigma_{P_{W} Y} h_{w Y} h_{w X}+i_{4} r_{p_{F}} \sigma_{P_{F} Y} h_{F Y} h_{F X}
\end{aligned}
$$

Where $i_{1}, i_{2}, i_{3}$, and $i_{4}$ are the selection intensities (BECKER, 1984), $\mathrm{h}_{\mathrm{X}} \mathrm{h}_{\mathrm{Y}}, \mathrm{h}_{\mathrm{FX}} \mathrm{h}_{\mathrm{FY}}$, and $\mathrm{h}_{\mathrm{WX}} \mathrm{h}_{\mathrm{WY}}$ are the cohertabilities, and $\sigma_{\text {py }}, \sigma_{\text {pfy }}, \sigma_{\text {pwy }}$ are the phenotypic standard deviations for mass, family and combined selection respectively. Selection intensities were chosen so that each selection-technique retained a similar number of trees (approximately 50 out of 962 trees).

\section{Results}

\section{Variation among Provenances and Families}

Survival was good in this study for all provenances with survival percentages above 90 percent till age 10 . However, provenance did not significantly affect survival at any age. At age 10, the Bienville Parish, LA provenance exhibited the best survival at 97.3 percent, while Okitibbeha Co., MS provenance was the lowest at 92.0 percent. The high survival rates among all provenances can be attributed to proper site selection, intense grading of the seedlings prior to planting, and the maintenance of the site following planting. Between ages 10 and 15, survival was shown to decrease sharply. This decrease in survival after age 10 probably is related to spacing as intense tree to tree competition became evident. In addition, provenance and family within provenance differences are being accentuated due to competition. Variability among provenances, while still not significant, began to increase with a decrease in survival. Difference in survival differences between the best and worst provenances was only 5.3 percent at age 10 but by age 15 that difference widened to 10 percent. Yet, the provenances themselves remained fairly constant in rankings (e.g., best and worst surviving provenances at age 10 kept the same rank at age 15). This demonstrates that the ability to select provenances with better survival does exist; however, without a survival model after inter-tree competition begins (i.e., after age ten in this study), accurate predictions will be hard to achieve. The drop in survival is also indicative of the need for wider spacing as the trees mature. Currently, the stand

Table 1. - Mean heights for eight cherrybark oak provenances included in the 1987 Cherrybark Oak Provenance- Progeny Test located in Carlisle Co., Kentucky.

\begin{tabular}{lllllll}
\hline Provenance & \multicolumn{7}{c}{ Mean Height (m) } \\
\cline { 2 - 6 } & \multicolumn{1}{c}{ Age 1 } & \multicolumn{2}{c}{ Age 3 } & Age 5 & \multicolumn{1}{c}{ Age 10 } & Age 15 \\
TN2 & $0.52 \mathrm{a}^{1}(1)^{2}$ & $1.31 \mathrm{c}(6)$ & $3.11 \mathrm{bc}(5.5)$ & $9.74 \mathrm{~cd}(7)$ & $14.52 \mathrm{~d}(8)$ \\
TN1 & $0.49 \mathrm{ab}(2.5)$ & $1.42 \mathrm{bc}(5)$ & $2.93 \mathrm{c}(8)$ & $9.48 \mathrm{~d}(8)$ & $14.76 \mathrm{~d}(7)$ \\
VA1 & $0.49 \mathrm{ab}(2.5)$ & $1.37 \mathrm{bc}(7)$ & $3.10 \mathrm{bc}(7)$ & $10.00 \mathrm{~cd}(6)$ & $14.89 \mathrm{~d}(6)$ \\
MS3 & $0.47 \mathrm{ab}(4.5)$ & $1.67 \mathrm{a}(1.5)$ & $3.76 \mathrm{a}(2)$ & $11.24 \mathrm{ab}(2)$ & $16.37 \mathrm{ab}(2)$ \\
MS2 & $0.47 \mathrm{ab}(4.5)$ & $1.67 \mathrm{a}(1.5)$ & $3.87 \mathrm{a}(1)$ & $11.56 \mathrm{a}(1)$ & $17.07 \mathrm{a}(1)$ \\
MS1 & $0.46 \mathrm{ab}(6.5)$ & $1.49 \mathrm{abc}(4)$ & $3.34 \mathrm{bc}(4)$ & $10.13 \mathrm{~cd}(5)$ & $15.27 \mathrm{~cd}(5)$ \\
LA2 & $0.46 \mathrm{ab}(6.5)$ & $1.54 \mathrm{ab}(3)$ & $3.51 \mathrm{ab}(3)$ & $10.66 \mathrm{abc}(3)$ & $16.03 \mathrm{bc}(3)$ \\
LA1 & $0.43 \mathrm{~b}(8)$ & $1.31 \mathrm{c}(8)$ & $3.11 \mathrm{bc}(5.5)$ & $10.46 \mathrm{bc}(4)$ & $15.75 \mathrm{bc}(4)$ \\
\hline
\end{tabular}

${ }^{1}$ Means followed by the same letter and case are not significantly different at the 0.05 probability level (Duncan's test).

2 Provenance ranking value for height. 
Table 2. - Mean diameters for eight cherrybark oak provenances included in the 1987 Cherrybark Oak Provenance- Progeny Test located in Carlisle Co., Kentucky.

\begin{tabular}{|c|c|c|c|}
\hline \multirow[t]{2}{*}{ Provenance } & \multicolumn{3}{|c|}{ Mean Diameter $(\mathrm{cm})$} \\
\hline & Age 5 & Age 10 & Age 15 \\
\hline MS3 & $3.99 \mathrm{a}^{1}(1.5)^{2}$ & $11.79 \mathrm{a} \quad(2)$ & $16.71 \mathrm{ab} \quad(2)$ \\
\hline MS2 & $3.99 \mathrm{a} \quad(1.5)$ & $11.91 \mathrm{a}(1)$ & $16.84 \mathrm{a}$ \\
\hline LA1 & $3.58 \mathrm{ab}$ & $11.07 \mathrm{ab}(3)$ & $15.52 \mathrm{~cd} \mathrm{(5)}$ \\
\hline MS1 & $3.45 \mathrm{abc}(4)$ & $11.02 \mathrm{ab}(4)$ & $15.63 \mathrm{bcd}(4)$ \\
\hline TN2 & $3.12 \mathrm{bcd}(5.5)$ & $10.29 \mathrm{bc}(7)$ & $14.10 \mathrm{e}$ \\
\hline VAl & $3.12 \mathrm{bcd}(5.5)$ & $10.59 \mathrm{bc}(6)$ & 14.91 cde (6) \\
\hline LA2 & $3.00 \mathrm{~cd}(7)$ & $10.82 \mathrm{bc}(5)$ & $15.90 \mathrm{abc}(3)$ \\
\hline TN1 & $2.87 \mathrm{~d}$ & $9.96 \mathrm{c}$ & $14.65 \mathrm{de}(7)$ \\
\hline
\end{tabular}

is undergoing considerable suppression with many of the intermediate trees falling into the suppressed class while the previous suppressed class is slowly dying off. This could have been avoided by thinning the stand at an earlier age such as following its tenth growing season.

Provenance differences were significant for height and diameter at each age of measurement. While overall height differences were significant at early ages, Duncan's new multiple range test showed that differences between the individual provenances were small and in many cases not significant (Table 1). The two best performing provenances for height at age 15 were from the Mississippi counties of Washington and Warren. These provenances were the tallest at age three; yet they were not significantly different from most of the other provenances until age 15. Few rank changes occurred over time for most provenances, however Bienville Parish, LA (LA1) provenance moved from eighth at age three to fourth at ages ten and fifteen in regards to height.

Diameter rankings did not significantly change between age five and age 10, but did between ages 10 and 15 (Table 2). The best performing provenances for diameter were the same as those that performed best for height. These provenances maintained their superiority through time. However the Washington Parish provenance showed a late age increase in diameter performance. This provenance ranked seventh at age five but an increase in diameter between ages 10 and 15 moved its ranking to third by age 15 .

Volume was significantly different among provenances at all ages, while ranks changed little over time. This is the same trend seen in both height and diameter and by age 15 the best performing sources for volume were the same as both height and diameter (Table 3). This is expected since the volume is a function of both variables.

Significant differences among families within provenances existed for height, diameter, and volume at all ages. At age 15, four of the top five families for height were from the Warren Co., MS provenance while the fifth family was from Washington Co., MS. The range of the top four families, all from Warren Co., MS, was 0.67 meters. The final family constituting the Warren Co., MS seed source ranked seventh with an average height of 16.43 meters; this further demonstrates the superiority of the Warren Co. provenance as well as the need for family considerations within a provenance. In regards to dbh at age 15, two of the top five families were from Washington Co., MS including the best overall family.

Table 3. - Mean volumes for eight cherrybark oak provenances included in the 1987 Cherrybark Oak Provenance- Progeny Test located in Carlisle Co., Kentucky.

\begin{tabular}{clcc}
\hline Provenance & \multicolumn{3}{c}{ Mean Volume (cubic meters) } \\
\hline & \multicolumn{1}{c}{$\underline{\text { Age 5 }}$} & $\underline{\text { Age 10 }}$ & $\underline{\text { Age 15 }}$ \\
MS2 & $0.007 \mathrm{a}^{1}(1)^{2}$ & $0.144 \mathrm{a}(1)$ & $0.411 \mathrm{a}(1)$ \\
MS3 & $0.006 \mathrm{a}(2)$ & $0.141 \mathrm{a}(2)$ & $0.399 \mathrm{a}(2)$ \\
LA1 & $0.005 \mathrm{ab}(3)$ & $0.117(3)$ & $0.330 \mathrm{bc}(4)$ \\
MS1 & $0.004 \mathrm{bc}(4)$ & $0.110 \mathrm{bcd}(5)$ & $0.319 \mathrm{bc}(5)$ \\
VA1 & $0.003 \mathrm{c}(6.5)$ & $0.100 \mathrm{bcd}(6)$ & $0.280 \mathrm{~cd}(6)$ \\
TN2 & $0.003 \mathrm{c}(6.5)$ & $0.092 \mathrm{~cd} \mathrm{(7)}$ & $0.248 \mathrm{~d}(8)$ \\
LA2 & $0.003 \mathrm{c}(6.5)$ & $0.113 \mathrm{bc} \mathrm{(4)}$ & $0.343 \mathrm{~b}(3)$ \\
TN1 & $0.003 \mathrm{c}(6.5)$ & $0.089 \mathrm{~d}(8)$ & $0.278 \mathrm{~cd}(7)$ \\
\hline
\end{tabular}

${ }^{1}$ Means followed by the same letter and case are not significantly different at the 0.05 probability level (Duncan's test).

${ }^{2}$ Provenance ranking value for $\mathrm{dbh}$. 
Table 4. - Individual tree, family mean, and within-family heritability estimates for height, diameter, and volume across all measurement ages included in the 1987 Cherrybark Oak Provenance-Progeny Test located in Carlisle Co., Kentucky. Standard errors are in parentheses.

\begin{tabular}{|c|c|c|c|c|c|c|c|c|c|}
\hline \multirow[t]{2}{*}{ Age } & \multicolumn{3}{|c|}{ Individual Tree $\mathrm{h}^{2}$} & \multicolumn{3}{|c|}{ Family h $^{2}$} & \multicolumn{3}{|c|}{ Within-Family $\mathrm{h}^{2}$} \\
\hline & $\underline{\text { Height }}$ & $\underline{\mathrm{DBH}}$ & $\underline{\text { Volume }}$ & $\underline{\text { Height }}$ & $\underline{\mathrm{DBH}}$ & Volume & $\underline{\text { Height }}$ & $\underline{\mathrm{DBH}}$ & $\underline{\text { Volume }}$ \\
\hline 1 & $\begin{array}{l}0.37 \\
(0.11)\end{array}$ & & & $\begin{array}{l}0.70 \\
(0.15)\end{array}$ & & & 0.31 & & \\
\hline 3 & $\begin{array}{l}0.18 \\
(0.07)\end{array}$ & & & $\begin{array}{l}0.51 \\
(0.10)\end{array}$ & & & 0.14 & & \\
\hline 5 & $\begin{array}{l}0.21 \\
(0.08)\end{array}$ & $\begin{array}{l}0.20 \\
(0.07)\end{array}$ & $\begin{array}{l}0.11 \\
(0.06)\end{array}$ & $\begin{array}{l}0.54 \\
(0.10)\end{array}$ & $\begin{array}{l}0.55 \\
(0.04)\end{array}$ & $\begin{array}{l}0.40 \\
(0.04)\end{array}$ & 0.17 & 0.16 & 0.09 \\
\hline 10 & $\begin{array}{l}0.28 \\
(0.09)\end{array}$ & $\begin{array}{l}0.36 \\
(0.11)\end{array}$ & $\begin{array}{l}0.28 \\
(0.09)\end{array}$ & $\begin{array}{l}0.65 \\
(0.12)\end{array}$ & $\begin{array}{l}0.70 \\
(0.04)\end{array}$ & $\begin{array}{l}0.65 \\
(0.04)\end{array}$ & 0.23 & 0.30 & 0.23 \\
\hline 15 & $\begin{array}{l}0.17 \\
(0.07)\end{array}$ & $\begin{array}{l}0.23 \\
(0.09)\end{array}$ & $\begin{array}{l}0.21 \\
(0.08)\end{array}$ & $\begin{array}{l}0.50 \\
(0.09)\end{array}$ & $\begin{array}{l}0.58 \\
(0.04)\end{array}$ & $\begin{array}{l}0.57 \\
(0.04)\end{array}$ & 0.13 & 0.16 & 0.16 \\
\hline Avg. & 0.24 & 0.26 & 0.20 & 0.58 & 0.61 & 0.54 & 0.20 & 0.21 & 0.16 \\
\hline
\end{tabular}

The second and third ranked families were from Warren Co., MS and the fifth family was from the west Tennessee Provenance (i.e., Lauderdale Co., Haywood Co, Fayette Co., Weakly Co., TN). The top three families were not different in dbh at age 15 . Top five volume producing families were all from Warren and Washington Co., MS.

\section{Genetic Gain from Direct Selection}

The large amount of variation existing among families allows gain to be made through selection within provenances. Narrow-sense individual, family mean, and within-family heritability were calculated. Family heritability was much greater than the individual tree heritability for all traits at all ages (Table 3). Individual, family, and within-family heritability for age-one height were consistently larger than their later ages. The high age-one heritabilities were subsequently followed by a drop in heritability at age three, a modest increase peaking at age 10 , and a slight drop at age 15 . This initial peak could be due to maternal effects or nursery effects (e.g., seedling grading). Overall, dbh heritability was the highest among the three traits. Volume had

Table 5. - Expected response from family selection relative to the expected response of mass selection for each trait and age of measurement included in the 1987 Cherrybark Oak Provenance- Progeny Test located in Carlisle Co., Kentucky.

\begin{tabular}{cccc}
\hline Age & \multicolumn{3}{c}{ Relative Response $\left(\mathrm{R}_{\mathrm{f}} / \mathrm{R}\right)$} \\
\hline & $\underline{\text { Height (\%) }}$ & DBH (\%) & Volume (\%) \\
1 & 0.63 & & \\
3 & 1.08 & & \\
5 & 1.19 & 1.15 & 1.15 \\
10 & 1.28 & 0.75 & 0.99 \\
15 & 1.78 & 0.93 & 1.53 \\
\hline
\end{tabular}

estimates comparable to height at ages 10 and 15 , but year-five estimates were consistently smaller.

The expected responses of mass-selection and familyselection were calculated using individual and family heritability estimates from Table 3. A comparison of responses between the two selection methods showed that, overall, selection based on family-means yielded greater expected responses than mass-selection (Table 4). Family selection showed a greater positive response at all ages except year-one. Selection based on familymean year 15 height had an expected response nearly 80 percent greater than mass-selection. Response due to family-selection was not nearly as great as height. Only at year-five would family-selection based on dbh be expected to yield a greater response than mass-selection. Expected responses of selection based on volumes

Table 6. - Comparison of family- and combined-selection predicted breeding values for volume at age 15 for the top three families in the 1987 Cherrybark Oak Provenance- Progeny Test located in Carlisle Co., Kentucky.

\begin{tabular}{|c|c|c|c|}
\hline \multirow[t]{2}{*}{$\begin{array}{l}\text { Phenotypic or } \\
\text { Predicted Genetic } \\
\text { Value } \\
\text { (cubic meters) }^{\mathrm{a}} \\
\end{array}$} & \multicolumn{3}{|c|}{ Family } \\
\hline & $\underline{4-5}$ & $\underline{5-4}$ & $\underline{5-5}$ \\
\hline$\left[\mathrm{y}_{\mathrm{ijkl}}-\mathrm{E}\left(\mathrm{y}_{\mathrm{ijkl}}\right)\right]$ & 13.96 & 14.02 & 14.80 \\
\hline$\left[\mathrm{y}_{. \mathrm{k} .}-\mathrm{E}\left(\mathrm{y}_{\text {..k. }}\right)\right]$ & 16.07 & 16.29 & 16.41 \\
\hline$\hat{\mathrm{g}}_{\mathrm{ijkl}}$ & 3.06 & 3.16 & 3.27 \\
\hline$\hat{\mathrm{g}}_{\mathrm{k}}$ & 3.74 & 3.92 & 4.02 \\
\hline
\end{tabular}


Table 7. - Additive genetic correlations (above the diagonal), phenotypic correlations (below the diagonal), and family and individual (in parentheses) heritabilities (along the diagonal) estimated from the 1987 Cherrybark Oak Provenance- Progeny Test located in Carlisle Co., Kentucky.

\begin{tabular}{|c|c|c|c|c|c|c|c|c|c|c|c|}
\hline \multirow{2}{*}{$\begin{array}{l}\text { Trait } \\
\text { and } \\
\text { Age }\end{array}$} & \multirow[b]{2}{*}{$\mathrm{Ht}(1)$} & \multicolumn{10}{|c|}{ Traits and Age } \\
\hline & & HT(3) & HT(5) & HT(10) & $\operatorname{HT}(15)$ & DBH(5) & $\mathrm{DBH}(10)$ & $\mathrm{DBH}(15)$ & VOL(5) & $\operatorname{VOL}(10)$ & VOL(15) \\
\hline HT(1) & $\begin{array}{l}0.70 \\
(0.37)\end{array}$ & 0.99 & 0.96 & 0.81 & 0.73 & 0.92 & 0.92 & 0.86 & 0.71 & 0.78 & 0.74 \\
\hline HT(3) & 0.47 & $\begin{array}{l}0.51 \\
(0.18)\end{array}$ & 0.92 & 0.86 & 0.94 & 0.97 & 0.88 & 0.90 & 0.95 & 0.82 & 0.84 \\
\hline HT(5) & 0.37 & 0.79 & $\begin{array}{l}0.54 \\
(0.21) \\
\end{array}$ & 0.93 & 0.94 & 0.93 & 0.88 & 0.90 & 0.91 & 0.88 & 0.88 \\
\hline HT(10) & 0.32 & 0.54 & 0.74 & $\begin{array}{l}0.65 \\
(0.28) \\
\end{array}$ & 1.04 & 0.86 & 0.80 & 0.93 & 0.72 & 0.79 & 0.91 \\
\hline HT(15) & 0.21 & 0.13 & 0.61 & 0.72 & $\begin{array}{l}0.50 \\
(0.17) \\
\end{array}$ & 0.90 & 0.72 & 0.79 & 0.91 & 0.78 & 0.82 \\
\hline DBH(5) & 0.42 & 0.82 & 0.90 & 0.69 & 0.57 & $\begin{array}{l}0.55 \\
(0.20) \\
\end{array}$ & 0.99 & 0.98 & 0.99 & 0.95 & 1.00 \\
\hline DBH(10) & 0.38 & 0.69 & 0.76 & 0.66 & 0.51 & 0.84 & $\begin{array}{l}0.70 \\
(0.36) \\
\end{array}$ & 0.97 & 0.89 & 0.94 & 0.97 \\
\hline $\mathrm{DBH}(15)$ & 0.31 & 0.59 & 0.66 & 0.60 & 0.58 & 0.70 & 0.92 & $\begin{array}{l}0.58 \\
(0.23)\end{array}$ & 0.15 & 0.90 & 0.98 \\
\hline VOL(5) & 0.41 & 0.80 & 0.83 & 0.60 & 0.49 & 0.91 & 0.74 & 0.621 & $\begin{array}{l}0.40 \\
(0.11) \\
\end{array}$ & 0.54 & 1.02 \\
\hline $\operatorname{VOL}(10)$ & 0.39 & 0.71 & 0.78 & 0.73 & 1.01 & 0.84 & 0.97 & 0.89 & 0.81 & $\begin{array}{l}0.65 \\
(0.28)\end{array}$ & 0.96 \\
\hline $\operatorname{VOL}(15)$ & 0.30 & 0.59 & 0.66 & 0.63 & 0.69 & 0.33 & 0.89 & 0.97 & 0.65 & 0.74 & $\begin{array}{l}0.57 \\
(0.21) \\
\end{array}$ \\
\hline
\end{tabular}

demonstrated that family-selection was generally superior. Family-selection based on year-five volume would be expected to have as much as a 53 percent greater response than mass selection.

Comparison of predicted breeding values for volume (age 15) from combined- and family-selection showed that on average combined-selection yielded a greater breeding value by +0.033 cubic meters. Individually however, the top five families received more volume gain from family selection. The top three families, which constitute the top ten percent of all families, had a predict- ed parental breeding value 0.73 greater than the breeding value of the best individual of that family (Table 5). This suggests that, while combined-selection may be better overall, selection of top volume producing families (e.g., top ten percent) may be better than selecting the top individuals within those top families through combined-selection.

\section{Genetic Gain from Indirect Selection}

Genetic age-age correlations $\left(r_{\alpha 1} \mathrm{r}_{\alpha 2}\right)$ between volume at age 15 and juvenile height, diameter, and volume

Table 8. - Correlated responses and genetic gains per unit time for age 15 volume from indirect selection for the 1987 Cherrybark oak provenance test in Carlisle Co., Kentucky.

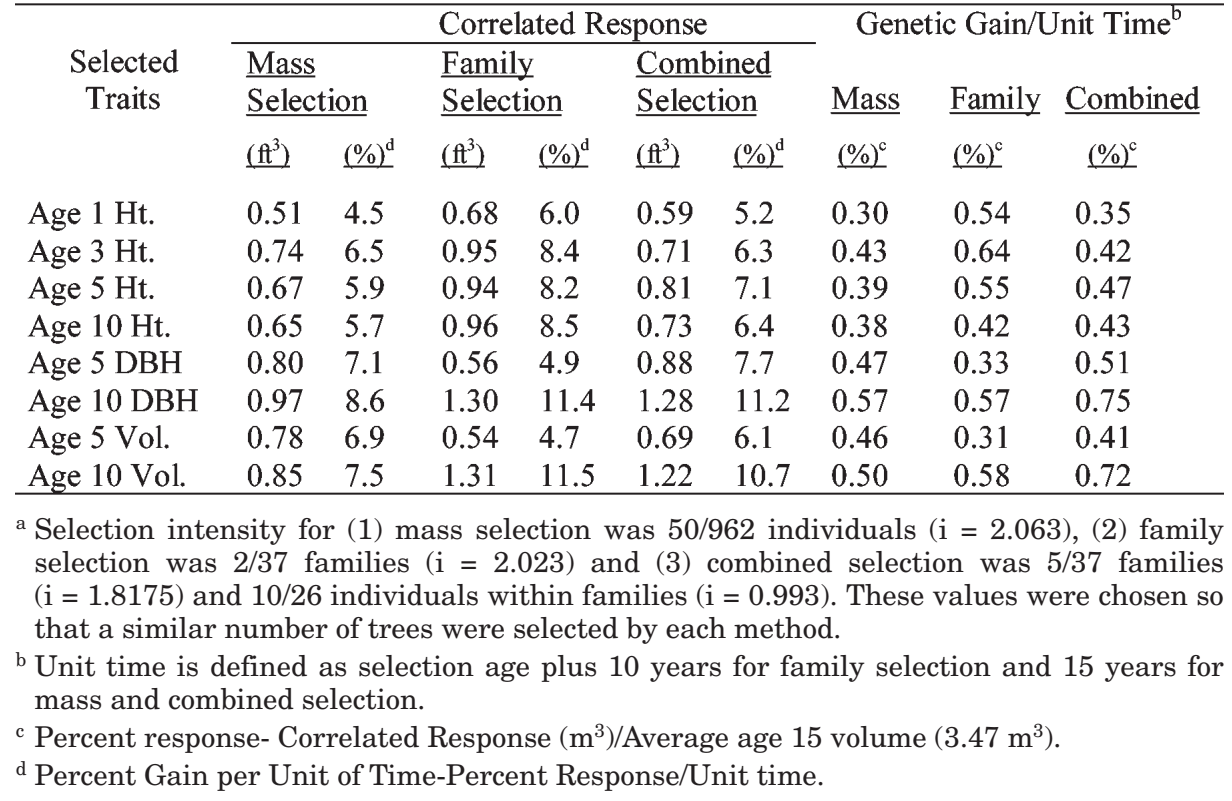


were strong (Table 6) with an average standard error of 0.051 (0.056-0.032). Early age height measurements at age one and age three showed positively-strong correlations with age- 15 volume, +0.78 and +0.84 respectively. However, these correlations are poor relative to correlations from traits measured at later ages. Juvenile diameter and volume had the strongest correlation with year15 volume that approached 1.0 and in the case of both diameter and volume at age five, approximated one.

Family selection yielded more gain per unit time than mass- or combined-selection when selections were based on height at any age before ten (Table 7). On the other hand, combined-selection was superior at maximizing genetic gain per unit time when making selections based on diameter or volume. Mass-selection was only superior when selecting volume at age five. Combined selection based on dbh at age-ten will allow the most gain per unit time to be made of any technique at any age.

\section{Discussion}

This study focused solely on growth aspects of various cherrybark seed sources up to age 15 . While this species is harvested as mature timber at a much later age, the ability of the tree to rapidly attain a co-dominant status allows for better form expression and greater acorn production, as the tree begins producing acorns at age 15 . Thus, breeding and selection decisions are needed at or before this age to ensure gains are made from seed orchard production. Inferences from this paper are somewhat limited because of only one study site; however, the seed sources used cover most of the natural range and provide insight into the genetic properties of this species.

Variation in height, diameter, and volume among both provenances and families within provenances were significant at all ages. Seed sources from Washington and Warren Counties, MS were superior for all traits. Trees from the two seed sources in Louisiana and the source from Okitibbeha, MS in Northern Mississippi generally produced the worst trees in regards to height, while both sources in Tennessee generally produced the worst trees in regards to both diameter and volume. This is different to the findings from GREENE et al. (1991), who reported growth of trees from Northwest Louisiana to be superior while trees from Southwest Mississippi to be only average performers. Survival was very high across all provenances from age one to age ten. After age 10 a sharp decrease in survival was observed which can be attributed to the onset of inter-tree competition.

No general trends were apparent among the provenances which support the study by SCHOENIKE et al. (1982). This is somewhat different to other species that do exhibit geographical patterns for growth and performance such as shortleaf pine (Pinus echinata Mill.) in the Southeastern U.S. (Wells 1973) or Northern red oak (Quercus rubra L.) in the North-Central U.S. (KRIEBEL et al. 1988). However, if the Virginia provenance is excluded, the better performing provenances were centralized in the range.
The large variation among families within a provenance, supported by GREEN et al. (1991), and high family heritability estimates highlight the need for family consideration when selecting within a seed source. The trend in individual tree height heritability in this study is comparable with the findings of FERGUSON and CoOper (1977). Their sweetgum (Liquidambar styraciflua L. ) study showed a relatively large height heritability of 0.25 at age two versus a much lower value of 0.08 at year-11. However, the height heritability estimates in the current study are low compared to individual height heritability estimates reported for other hardwood species such as a year-one black walnut estimate of 0.55 (MCKEAND, 1978) and yellow poplar estimates ranging from 0.42 to 0.84 (KELLISON, 1970). GwAZE et al. (2003) reported a range in Nuttall oak (Quercus nuttallii Palmer) family heritability of 0.72 to 0.96 for height and 0.22 to 0.95 for diameter. On the other hand, RousseAu (1989) reported that sycamore (Platanus occidentalis L.) had height and volume family heritability estimates, 0.36 to 0.71 and 0.51 to 0.46 respectively, that were similar to those found in this study.

Existing variation among families allows for gains to be made through selection. Mass-selection, family-selection, and combined-selection were evaluated for (1) maximization of trait gain through direct selection and (2) maximization of volume gain at age 15 through indirect selection based on juvenile traits. Mass-selection generally produced a smaller response than family-directselection of any trait. Comparison of combined- and family-selection showed that overall the combined-selection produced greater breeding values. However, familyselection could be expected to yield greater direct gains than combined-selection in regards to top families. The better overall performance of combined-selection on direct trait selection is comparable to the finding of DAVID et al. (2003). Their study on red pine (Pinus resinosa Ait.) showed that expected selection gain for combined-selection, termed "family+within-family" in their study, was 10.58 percent while family selection only yielded expected gains of 9.13 percent.

Selection from juvenile traits can be an efficient method for acquiring genetic gain while minimizing rotation time. High genetic correlations between volume at age 15 and other juvenile-traits allow for more of the heritable variance to be captured and allow the minimization of the breeding cycle. GwAzE et al. (1997) defined the optimum selection age as the age which maximizes the annual genetic gain. Maximization of genetic gain per-time through indirect selection has been used by Foster (1986) and Rousseau (1987) in eastern cottonwood (Populus deltoides Bartr ex. Marsh.) and by Rousseau (1989) in American sycamore. Findings from the current study were similar to the two eastern cottonwood studies which found that optimal selection occurred at age 10 based on either diameter or volume.

Mass-selection yielded smaller gain from both indirect and direct selection than family- and combined-selection. This can be directly attributed to relatively low 
narrow-sense individual-tree heritability compared to family-heritability. Family-selection is optimum for height before age 10 because of the small height-withinfamily correlation that is included in the combinedselection calculation. However, both height and diameter within-family correlations are high and allow combined-selection to yield gains higher than family-selection. While combined-selection of volume and dbh at age 10 both produced the greatest correlated response percentage (11.2 and 10.7 percent respectively) and genetic gain per unit time percentage $(0.75$ and 0.72 percent respectively), family-selection genetic gain per unit time percent was only slightly less ( 0.64 percent). If grafting and acorn production time can be reduced below 10 years (as used in this study), family-height-selection at age three will be comparable to combined selection gain from volume or height.

In conclusion, cherrybark oak seed should be collected from areas in west Mississippi for both superior height and superior diameter growth for deployment in Western Kentucky and west Tennessee. Large amounts of variation existed among families within a provenance demonstrating the importance of family considerations. Using combined-selection based on age 10 volume or $\mathrm{dbh}$ will maximize genetic age 15 volume gain per unit time.

\section{Acknowledgement}

This manuscript is publication \#FO- 309 of the Forest and Wildlife Research Center, Mississippi State University.

\section{References}

ADAMS, J. C. (1989): Five year growth results of water oak (Quercus nigra L.) provenances. Proceedings $20^{\text {th }}$ Southern Forest Tree Improvement Conference, pp. 310-314.

BECKER, W. A. (1975): Manuel of Quantitative Genetics. $3^{\text {rd }}$ Ed. 170pp. Washington State University Press, Pullman, Washington.

David, A., C. Pike and R. Stine (2003): Comparison of selection methods for optimizing genetic gain and gene diversity in a red pine (Pinus resinosa Ait.) seedling seed orchard. Theoretical and Applied Genetics 107: 843-849.

FALCONER, D. S. and T. F. C. MACKAY (1996): Introduction to Quantitative Genetics. $4^{\text {th }}$ Ed. 457pp. Pearson Prentice Hall, Harlow, England.

Ferguson, R. B. and D. T. Cooper (1977): Sweetgum variation change with time. $14^{\text {th }}$ Southern Forest Tree Improvement Conference, Gainesville, Florida, pp 194-200.

FosteR, G. S. (1986): Genetic Parameters for two eastern cottonwood populations in the lower Mississippi valley. Proceedings $18^{\text {th }}$ Southern Forest Tree Improvement Conference, pp. 258-266.

Greene, T. A., W. J. Lowe and M. Stine (1991): Volume production of six cherrybark oak provenances in the western gulf region. In: Proceedings of the sixth biennial southern silvicultural research conference; 1990 October 30-November 1; Memphis, TN. General Technical Report SE-70, edited by S. S. ColEMAN and D. G. NEARY, 736-743. Asheville, NC: U.S. Department of Agriculture, Forest Service, Southern Research Station.
Gwaze, D. P., T. D. Byram and E. M. Raley (2003): Performance of Nuttall oak (Quercus texana Buckl.) provenances in the western gulf region. Proceedings $27^{\text {th }}$ Southern Forest Tree Improvement Conference, pp. 126-137.

Gwaze, D. P., J. A. Wodliams and P. J. Kanowski (1997): Optimum selection age for height in Pinus taeda L. in Zimbabwe. Silvae Genetica 46: 358-365.

HARI, G. (1988): 1987 Cherrybark oak provenances-progeny test. Establishment Report No. Westvaco Central Forest Research Center, Wickliffe, KY. 9p.

Hodge, G. R. and T. L. White (1992): Concepts of Selection and Gain Prediction. Chapter 4. In: Handbook of Quantitative Forest Genetics. L. Fins, S. T. FrIEdman, and J.V. BROTSCHOL eds.

Kellison, R. C. (1970): Phenotypic and genotypic variation of yellow-poplar (Liriodenron tulipifera). $\mathrm{PhD}$ thesis, Department of Forestry, North Carolina State Univeristy, Raleigh.

Kriebel, H. B., C. MerritT and T. Stadt (1988): Genetics of growth rate in Quercus rubra: provenance and family effects by the early third decade in North Central U.S.A. Silvae Genetica 37: 193-198.

McKeand, S. E. (1978): Analysis of half-sib progeny tests of black walnut. MS thesis, Department of Forestry and Natural Resources, Purdue University, Lafayette, Indiana.

Namkoong, G., E. B. Snyder and R. W. Stonecypher (1966): Heritability and Gain Concepts for Evaluating Breeding Systems such as Seedling Orchards. Silvae Genetica 15: 76-84.

Osborne, R. and W. S. B. Paterson (1952): On the sampling variance of heritability estimates derived from sampling analysis. Proc. R. Soc. Edinb. Sect. B. 64: 456-461.

Rousseau, R. J. (1987): Genetic Variance among selected cottonwood clones: Seven-year results. Proceedings of the fifth North Central Tree Improvement Conference. North Dakota University. 34-42.

Rousseau, R. J. (1989): Genetic Performance and earlyage selection within a ten-year old mid-west sycamore progeny test. Proceedings of the $20^{\text {th }}$ Southern Forest Tree Improvement Conference, pp. 294-301.

SAS Institute Inc. (1999): SAS User's Guide. Statistics, Version 8. Carey, North Carolina. SAS Institute Inc.

Schoenike, R. E., T. A. Benson and T. A. Astriab (1982): Ten-year growth of forty-three seed sources of southern red oak (Quercus falcate Michx.) in two Piedmont South Carolina plantations. Forestry Bulletin 33. Clemson, SC: Dept. of Forestry, Clemson Univ. 8 pp.

Stein, J., D. Binion and R. AcciavatTi (2003): Field Guide to Native Oak Species of Eastern North America. Morgantown, WV: Forest Health Technology Enterprise Team, USDA Forest Service, FHTET-2003-01.

Wells, O. O. (1973): Variation among Shortleaf Pine in a Mississippi seed source planting: U.S. Forest Service Research Note, Soutern Forest Experiment Station; (SO-162): 8 pp.

Yuceer, M. C., J. D. Hodges, S. B. LAND, JR. and A. L. FRIEND (1998): Upland vs. bottomland seed sources of cherrybark oak. In: Proceedings of the ninth biennial southern silvicultural research conference; 1997 February 25-27; Clemson, S. C. General Technical Report SRS-20, edited by T. A. WALDROP, 215-221. Asheville, NC: U.S. Department of Agriculture, Forest Service, Southern Research Station. 